\title{
KARAKTERISASI DAN IDENTIFIKASI MOLEKULER BAKTERI PENGHASIL ENZIM PROTEASE DARI TEMPE YANG DIPERJUALBELIKAN DI PASAR LUBUK PAKAM
}

\section{VISENSIUS KRISDIANILO', ${ }^{1}$ SA'ADAH SIREGAR $^{2}$, VICENTIA ADE $^{\prime}$ RIZKY ${ }^{3}$}

\author{
PROGRAM STUDI D IV TEKNOLOGI LABORATORIUM MEDIK, FAKULTAS \\ FARMASI, INSTITUT KESEHATAN MEDISTRA LUBUK PAKAM. \\ e-mail :chrizdianilo@gmail.com \\ DOI : https://doi.org/10.35451/jfm.v4i1.616
}

\begin{abstract}
Protease enzyme is an enzyme that is important in protein breakdown. Animals, plants as well as microorganisms such as bacteria can produce this protease enzyme. In its application protease enzymes can be used in the pharmaceutical industry, detergent industry, skin products as well as food products. Tempe is one of the traditional food products that have been known for a long time, tempeh is made from soybean seeds fermented by mushrooms. Molecular identification can use polymerase chain reaction (PCR) method, PCR is the process of multiplying a certain nucleotide sequence using enzymatic processes in vitro. The presence of protein content in tempeh can be possible the presence of bacteria that can break down proteins in the tempeh, especially tempeh that has been fermented about 48-72 hours. Based on the results of characterization and identification of 5 isolates of tempeh post-fermentation 72 hours, positive results of protease enzymes found in isolate TPLP-1, TPLP-2 and TPLP-5, with the largest zone diameter in isolate TPLP-2 $50 \mathrm{~mm}$, then isolate with the highest protease enzyme activity isolate TPLP-2 molecularly identified by identifying the gene $16 \mathrm{~S}$ rRNA which is subsequently included in the BLAST program and obtained by isolate TPLP-2 identified as Pseudomons stuastzeri.
\end{abstract}

Keywords : Bacterial, Enzyme Protease, Pseudomons stuastzeri , Tempe

\section{PENDAHULUAN}

Semakin berkembangnya ilmu dan teknologi mendorong peneliti untuk terus mencari bahan bahan yang berpotensi sebagai sumber enzim protease.Enzim protease bersifat esensial serta sangat diperlukan oleh semua mahluk hidup dalam proses metabolism protein (Baehaki dan Rinto, 2011)

Enzim protease merupakan enzim yang penting dalam pemecahan protein.Hewan, tanaman serta mikroorganisme seperti bakteri dapat menghasilkan enzim protease ini. Dalam aplikasinya enzim protease dapat digunakan dalam industry farmasi, 
industry detergen, produk-produk kulit serta produk-produk makanan (Fatonidkk., 2008).

Tempe menjadi salahsatu produk makanan tradisional yang telah dikenal lama, tempe dibuat dari biji kedelai yang di fermentasi oleh jamur, membentuk padatan kompak. Kandungan dalam 100 g tempe terdapat karbohidrat 350.5 380.8 kalori, lemak $20-20.1 \mathrm{~g}$ dan protein 16.7-17.9 g (Efriwati dan Nuraida 2013). Adanya kandungan protein dalam tempe dapat dimungkinkan adanya bakteri yang dapat memecah protein pada tempe tersebut, terutama tempe yang telah di fermentasi sekitar 48 - 72 jam.

Identifikasi molekuler dapat menggunakan metode Polymerase Chain Reaction (PCR), PCR adalah proses melipat gandakan suatu sekuens nukleotida tertentu menggunakan proses enzimatik secara in vitro. (Darmawati dkk. 2014).

Penelitian yang dilakukan oleh Inayatul dkk pada tahun 2018, tentang Isolasi Dan Identifikasi Molekuler Bakteri Penghasil Enzim Protease Pseudomonas Stutzeri ISTD4 Dari Tempe Gembus Pasca Fermentasi 1 Hari, didapatkan hasil analisis molekuler bebasis sekuen gen 16S rRNA, isolate ISTD4 teridentifikasi sebagai Pseudomonas stutzeristrain ISTD-1. Sedangkan penelitian yang dilakuakn oleh Mony dkk. Pada tahun 2018, tentang Isolasi Dan Identifikasi Molekuler Bakteri Penghasil Enzim Protease Pada Tempe Gembus Pasca Fermentasi 48 Jam Berdasarkan Analisis Gen 16S rRNA, di dapatkan hasil dari isolate ISTD 2.1 adalah Bacillus cereus.

\section{METODE PENELITIAN}

Metode yang digunakan pada penelitian ini adalah deskriptif analitik. Sampel pada penelitian ini diambil dari penjual tempe di pasar lubuk pakam, kemuduan dibawa ke laboratorium
Mikrobiologi Fakultas Farmasi Institut Kesehatan Medistra Lubuk Pakam, sedangkan objek pada penelitian ini adalah enzim protease dari bakteri Pseudomonas Stutzeri pada tempe pasca fementasi 72 jam. Sampel tempe yang didapat sejumlah 17 sampel, kemudian dari masing masing sampel diambil $3 \mathrm{~g}$ dan dihaluskan serta di homogenkan menggunakan lumpang.

Pengisolasian dilakukan dengan terlebihdengan memberi label pada tabung reaksi $10^{-1}-10^{-5}$, memasukan $\mathrm{NaCl}$ fisiologis sebanyak $9 \mathrm{ml}$ kedalam semua tabung reaksi. Menimbang 1 gram sampel tempe pasca fermentasi 72 jam, kemudian memasukanya kedalam tabung reaksi yang tidak dilakukan pengenceran yang berisi $\mathrm{NaCl}$ fisiologis kemudian di homogenkan menggunakan vortex.Mengambil $1 \mathrm{ml}$ dari tabung tanpa pengenceran kemudian dimasukan kedalam tabung $10^{-1}$ kemudian di homogenkan, lakukan langkah tersebut sampai pada pengenceran $10^{-5}$.langkah selanjutnya yaitu menanam dari tabung pengenceran $10^{-1}-10^{-5}$ di media nutrient agar dan diinkubasi pada suhu $37^{\circ} \mathrm{C}$ selama 24 jam, setelah 24 jam dilakukan pengamatan makroskopis dan mikroskopis. Kemudian melakukan tahapan permurniankoloni bakteri sampai diperoleh beberapa isolate murni.

Identifikasi makroskopis dapat diamati dengan melihat bentuk koloni, ukuran koloni, pinggiran koloni, warna koloni, permukaan koloni, dan konsistensi koloni pada media isolasi. Identifikasi mikroskopis mikroba dilakukan dengan pewarnaan, yaitu dengan mengambil koloni bakteri yang telah dibiakan menggunakan ose, kemudian diletakan pada objek gelas dan memfiksasinya menggunakan api bunsen, selanjutnya mewarnai bakteri dengan menetesi bakteri dengan reagen gentian violet sekitar $2-3$ tetes, tunggu 
1 menit dan bilas pada air mengalir, kemudian meneteskan lugol/iodine sebanyak 2-3 tetes, tunggu sekitar 1 menit dan cuci di air mengalir, dilanjutkan meneteskan alcohol 96\%, tunggu 30 detik dan cuci pada air mengalir kembali, setelah lumayan kering, tahap selanjutnya meneteskan safranin sebanyak 2-3 tetes dan tunggu sekitar 10 detik dan bilas dengan air mengalir dan keringkan, setelah kering bakteri yang telah diwarnai diamati di bawah mikroskop dengan pembesaran 1000x dengan penambahan oil imercy, hasil pengamatan dilihat bentuk sel bakteri nya dan warna dari bakteri ( Prescot, 1990).

Pengujian bakteri secara biokimia dilakukan dengan pengujian uji motilitas, uji triple sugar iron agar (TSIA), uji simon sitrat, dan uji gelatin. Pemerikisaan adanya enzim protease dilakukan menggunakan media skim milk agar. Koloni murni yang didapat ditanam secara dotting dengan kertas wattman pada media skim milk agar selanjutnya media diinkubasi pada suhu $37^{\circ} \mathrm{C}$ selama 24 jam. Adanya zona bening disekitar koloni menunjukan adanya enzim protease.

Pemeriksaan molekuler pada isolate dilakukan dengan analisa gen $16 S$ rRNA. Langkah awal dengan mengekstraksi DNA genom menggunakan kit isolasi DNA GeneaidTM. DNA template sebanyak $1 \mu \mathrm{L}$ dicampur dengan larutan PCR sebanyak $25 \mu \mathrm{L}$ yang terdiri dari $1 \mu \mathrm{L}$ forward primer, $1 \mu \mathrm{L}$ reverse primer, 12,5 $\mu \mathrm{L}$ GoTaq Green Master Mix, 0,5 $\mu \mathrm{L}$ DMSO dan $9 \mu \mathrm{L}$ nuclease-free water. Larutan Primer yang dipakai adalah 27 F: 5 ` - AGA GTT TGA TCC TGG CTC AG $3^{`}$ dan 1492 R: 5 ` - GGT TAC CTT GTT ACG ACT T - 3` ( Srinivasan, 2015).

Hasil campuran PCR kemudian diletakan ke dalam mesin PCR dengan pengaturan yaitu proses denaturasi awal $96^{\circ} \mathrm{C}$ selama 5 menit, dilanjutkan dengan proses denaturasi sebanyak 30 siklus pada suhu $96^{\circ} \mathrm{C}$ selama 30 detik, untuk proses annealing pada suhu 55 - C selama 30 detik, dan pemanjangan untaian pada $72 \circ \mathrm{C}$ selama 1 menit. Setelah selesai 30 siklus, final extension pada suhu $72^{\circ} \mathrm{C}$ selama 7 menit. Hasil amplifikasi PCR kemudian dielektroforesis pada gel agarosa $(1,5 \%)$ dalam buffer $T A E$, selanjutnya divisualisasikan dengan pewarnaan dengan Gel Red serta dianalisis dengan Gel Documentation. Hasil amplifikasi diurutkan dengan menggunakan sekuenser DNA otomatis (ABI PRISM 3130 Genetic Analyzer) untuk menentukan urutan dari untai DNA.Data untaian DNA yang didapat kemudian dilakukan pemangkasan data dan dirangkai menggunakan program BioEdit(http://www.mbio.ncsu.edu/Bio Edit/bioedit.html). Untuk melihat takson / spesies dengan kemiripan molekul terbesar dan terdekat, menggunakan program BLAST, data terdaftar di GenBank, dan perangkat dari NCBI / National Center for Biotechnology Information (http: //www.ncbi.nlm.nih) .gov / BLAST /)(Kumar et al., 2018 dan Facrial et al., 2020).

\section{HASIL DAN PEMBAHASAN}

Hasil dari isolasi pada sampel tempe disapatkan 5 isolat, dengan masimg-masing diberi koding TPLP-1, TPLP-2, TPLP-3, TPLP-4, dan TPLP-5.

Isolat yang didapat kemudian dilakukankan identifikasi secara makroskopis dan mikroskopis dengan pewarnaan gram. Hasil makroskopis didapat didominasi bentuk koloni nya circular, untuk permukaan koloni didominasi berbentuk Entire, dengan tepian koloni seluruhnya Flat, serta warna koloni yang didominasi berwarna krim, selain itu terdapat juga warna coklat, krim kuning dan krim bening. Pemeriksaan makroskopis bakteri digunakan untuk membedakan jenis 
dari bakteri berdasarkan dari bentuk koloni, permukaan, tepi koloni dan warna koloni.

$$
\text { Pemeriksaan makroskopis }
$$

bakteri sebagian besar menggunakan pewarnaan gram, pemeriksaan ini digunakan sebagai pemeriksaan awalan terhadap identifikasi suatu bakteri. Hasil yang didapat dari pewarnaan gram pada 5 isolat yang didapat yaitu sebagian besar isolate merupakan bakteri Gram $(-)$, Basil, sedangkan yang $\operatorname{Gram}(+)$, Basil hanya pada isolate TPLP-3 dan TPLP-4. Pewarnaan gram digunakan sebagai pembeda dari jenis bakteri berdasarkan struktur dinding sel nya. Pada dinding bakteri gram positif memiliki peptidoglikan yang tebal, bakteri yang diberi pewarna gentian violet maka baik bakteri gram positif atau negative seluruhnya akan menyerap zat warna gentian violet akan tetapi ketika diberi alcohol bakteri gram negative akan luntur dikarenakan sebagian besar tersusun dari lipid, sehingga pada saat diberikan pewarna safranin maka bakteri gram negative tersebut akan menyerap zat warna dari safranin yang menyebabkan bakteri gram negative akan berwarna merah, sedangkan bakteri gram positif akan tetap mempertahankan warna violet yang diakibatkan karena tebalnya lapisan peptidoglikan pada dinding sel bakteri tersebut (Baehaki et al., 2019).

Identifikasi bakteri secara biokimia terhadap 5 isolat yang didapat, hasil uji motilitas didominasi motilitas $(+)$, uji simonsitrat dan gelatin di dominasi hasil negative $(-)$, sedangkan uji TSIA di dominasi warna media merah kuning (MK), serta seluruh isolate tidak terdapat $\mathrm{H}_{2} \mathrm{~S}$.

Tabel 1. Hasil pemeriksaan makroskopis

\begin{tabular}{lllll}
\hline Isolat & $\begin{array}{l}\text { Bentuk } \\
\text { Koloni }\end{array}$ & $\begin{array}{l}\text { Permukaan } \\
\text { Koloni }\end{array}$ & Tepi Koloni & Warna Koloni \\
\hline TPLP-1 & Circular & Entire & Flat & Krim \\
TPLP-2 & Circular & Entire & Flat & Coklat \\
TPLP-3 & Irregular & Undulate & Flat & Krim Kuning \\
TPLP-4 & Circular & Entire & Flat & Krim \\
TPLP-5 & Circular & Undulate & Flat & Krim Bening \\
\hline
\end{tabular}

Tabel 2. Hasil pemeriksaan mikroskopis

\begin{tabular}{ll}
\hline Isolat & Hasil Pewarnaan Gram \\
\hline TPLP-1 & Gram (-), Basil \\
TPLP-2 & Gram (-), Basil \\
TPLP-3 & Gram (+), Basil \\
TPLP-4 & Gram (+), Basil \\
TPLP-5 & Gram (-),Basil \\
\hline
\end{tabular}

Gambar 1. (a) Isolate TPLP-2 (Gram Negative), (b) Isolat TPLP-3 (Gram Positif )
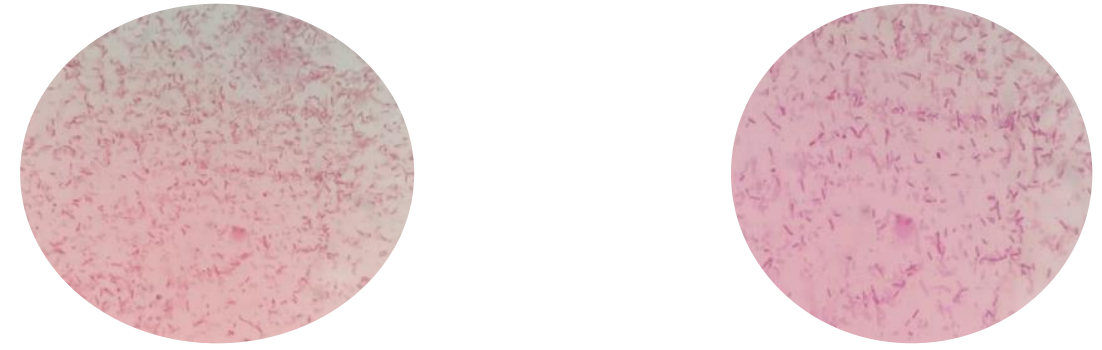
Tabel 3. Hasil identifikasi biokimia

\begin{tabular}{ccccc}
\hline Isolat & Uji Motilitas & Uji TSIA & $\begin{array}{c}\text { Uji Simon } \\
\text { Sitrat }\end{array}$ & Uji Gelatin \\
\hline TPLP-1 & $(+)$ & KK & $(+)$ & $(+)$ \\
TPLP-2 & $(+)$ & KK & $(+)$ & $(+)$ \\
TPLP-3 & $(+)$ & MK & $(-)$ & $(-)$ \\
TPLP-4 & $(-)$ & MK & $(-)$ & $(-)$ \\
TPLP-5 & $(-)$ & MK & $(-)$ & $(+)$ \\
\hline
\end{tabular}

Pemeriksaan adanya enzim protease pada5 isolate menggunakan media skim milk agar, dengan hasil positif ditandai dengan terbentuknya zona transparan disekitar koloni bakteri. Hasil uji enzim protease didapat hasil positif pada isolate TPLP-1, TPLP-2 dan TPLP-5, sedangkan hasil negative terdapat pada isolate TPLP-3 dan TPLP4. Diameter yang dihasilkan dari zona transparan paling besar pada isolate TPLP-2. Zona transparan disekitar koloni besaran nya sangat dipengaruhi oleh jumlah enzim protease yang dihasilkan oleh bakteri tersebut serta jumlah nutrisi yang terkandung pada medianya, media skim milk agar mengandung nutrisi yang sangat banyak dab variatif seperti adanya fosfor, magnesium, kalsium dan kasein sehingga bila jumlah nutrisinya kurang akan mempengaruhi hasil dari aktivitas enzim proteasenya (Chekireb et al., 2009 dan Gupta et al., 2005).

Isolalat yang telah di periksa adanya enzim protease dari kelima isolate didapat hasil isolate yang positif adanya enzim protease serta memiliki zona paling lebar terdapat pada isolate TPLP-2, isolate tersebut kemudian diidentifikasi secara molekuler dengan pemeriksaan sekuens Gen 16S rRNA, hasil sekuens Gen 16S rRNA pada isolate TPLP-2 kemudian dimasukan ke program BLAST untuk melihat kemiripan/takson dengan spesies bakteri lain. Hasil yang didapat pada isolate TPLP-2 memiliki kemiripan dengan Pseudomonas stutzeri.

Hasil tersebut serupa dengan penelitian yang dilakukan oleh Inayatul dkk pada tahun 2018, tentang Isolasi Dan Identifikasi Molekuler Bakteri Penghasil Enzim Protease Pseudomonas Stutzeri ISTD4 Dari Tempe Gembus Pasca Fermentasi 1 Hari, didapatkan hasil analisis molekuler bebasis sekuen gen 16S rRNA, isolate ISTD4 teridentifikasi sebagai Pseudomonas stutzeri strain ISTD-1. Bakteri Pseudomonas stutzeri merupakan bakteri gram negative basilyang bersifat aerobik, bakteri tesebut menghasilkan uji katalase dan oksidase positif serta dapat tumbuh pada maltose dan pati.Bakteri Pseudomonas stutzeri memiliki bentuk koloni berwarna coklat kemerahan serta koloni yang kering (Zahra, 2016).

Dapat diketahu bawasanya tempe pasca fermentasi selama 72 jam memiliki potensi sebagai tempat dari bakteri penghasil enzim protease dikarenakan pada tempe terdapat kandungan proteinnya, sehingga tempe pasca fermentasi selama 72 jam dapat dimanfaatkan sebagai sumber bakteri penghasil enzim protease yang nantinya enzim protease nya dapat dimanfaatkan dalam skala industri. 
Tabel 4. Hasil uji adanya enzim protease

\begin{tabular}{ccc}
\hline Isolat & $\begin{array}{c}\text { Hasil Uji Enzim } \\
\text { Protease }\end{array}$ & Diameter \\
\hline TPLP-1 & $(+)$ & $28 \mathrm{~mm}$ \\
TPLP-2 & $(+)$ & $50 \mathrm{~mm}$ \\
TPLP-3 & $(-)$ & 0 \\
TPLP-4 & $(-)$ & 0 \\
TPLP-5 & $(+)$ & $17 \mathrm{~mm}$ \\
\hline
\end{tabular}

\section{KESIMPULAN}

Berdasarkan hasil karakterisasi dan identifikasi terhadap 5 isolat tempe pasca fermentasi 72 jam, didapatkan hasil positif adanya enzim protease terdapat pada isolate TPLP-1, TPLP-2 dan TPLP-5, dengan diameter zona paling besar pada isolate TPLP-2 $50 \mathrm{~mm}$, selanjutnya isolate dengan aktivitas enzim protease paling tinggi yaitu isolate TPLP-2 di identifikasi secara molekuler dengan mengidentifikasi gen 16S rRNA yang selanjutnya dimasukan di program BLAST dan didapatkan bawasanya isolate TPLP-2 teridentifikasi sebagai Pseudomonas stutzeri.

\section{DAFTAR PUSTAKA}

Baehaki A, Nopianti R, Saputra E, Gofar N. 2019. Exploration of protease enzyme producing bacteria from water in tanjung senai swamp Indralaya South Sumatra. In: Herlinda $\mathrm{S}$ et al. (Eds.), Prosiding Seminar Nasional Lahan Suboptimal 2019, Palembang 4-5 September 2019. pp. 121-131. Palembang: Unsri Press.

Baehaki.A dan Rinto.2011. Karakteristik Protease dari Isolat Bakteri Asal Tumbuhan Rawa dari Indralaya.Jurnal. Program Studi Teknologi Hasil Perikanan, Fakultas Pertanian Universitas Sriwijaya. Palembang.

Chekireb D, Tahar A and Cochet N. 2009.Acid Protease Production by Isolated Species of
Penicillium.European Journal of Scientific Research.25: (3) 469-477. Darmawati,S., Sembiring,L., Asmara,S., Artama.W.T., Kawaichi.M. 2014. Phylogenetic relationship of Gram Negative Bacteria of Enterobacteriaceae Family in the Positive Widal Blood Cultures based on 16S rRNA Gene Sequences. Indonesian Journal of Biotechnology.Vol. 19, No. 1, pp.6470.

Fachrial EDY, Roro R, Satyo J, Lister INE, Anggraini S, Nugroho TT. 2020. Molecular identification of cellulase and protease producing Bacillus tequilensis UTMSA14 isolated from the geothermal hot spring in Lau Sidebuk Debuk, North Sumatra , Indonesia. 21(10):4719-25.

Fatoni, A. Z. dan Puji, L. 2008.Isolasi dan Karakterisasi Protease Ekstraseluler dari Bakteri dalam Air Tahu.Jurnal Natur Indonesia.

Gupta R, Beg Q, Lorenz P. 2002. Bacterial alkaline proteases: molecular approaches and industrial applications. Applied microbiology and biotechnology. 59(1):15-32.

Inayatul dkk. 2019. Isolasi dan identifikasi molekuler bakteri penghasil enzim protease Pseudomonas stutzeri ISTD4 dari tempe gembus pasca fermentasi 1 hari. Seminar Nasional Edusainstek FMIPA UNIMUS.

Kumar S, Stecher G, Li M, Knyaz C, Tamura K. 2018. MEGA X: Molecular 
Evolutionary Genetics Analysis across computing platforms. Mol Biol Evol 35 . (6): 1547-1549.

Mony Nining. 2018. Isolasi Dan Identifikasi Molekuler Bakteri Penghasil Enzim Protease Pada Tempe Gembus Pasca Fermentasi 48 Jam Berdasarkan Analisis Gen 16S rRNA. Repository Unimus.

Prescot, Harley, Klein. 1990. Microbiology. Second edition.WCB Publisher. England.

Srinivasan $R$, Karaoz $U$, Volegova $M$, MacKichan J, Kato-Maeda M, Miller
S, Nadarajan R, Brodie EL, Lynch SV. 2015. Use of 16S RRNA gene for identification of a broad range of clinically relevant bacterial pathogens. PLOS ONE 10 (2): 1-22. DOI:

10.1371/journal.pone.0117617.

Zahra Kamil Kadhim. 2019.Isolation and Identification of Pseudomonas stutzeri Isolated from Intrauterine Devices. Al-Kufa University Journal for Biology / VOL.8/ NO.3. 